\title{
The Relationship of the Renal Vascular Activity of Angiotensin II to the Autonomic Nervous System *
}

\author{
John C. McGiff $†$ and Thomas M. Fasy \\ (From the Departments of Pharmacology and Medicine, School of Medicine, University of \\ Pennsylvania, and the Edward B. Robinette Foundation, Medical Clinic, Hospital of the \\ University of Pennsylvania, Philadelphia, Pa.)
}

The vasoconstrictor activity of angiotensin II was originally considered to be due to a direct effect on vascular smooth muscle $(1,2)$. Subsequently, it has been suggested that the sympathetic nervous system participates in the vascular response to angiotensin II (3-5). After acute denervation of the limb, the reactivity of the limb vasculature to angiotensin II is reduced in the rat (3) and dog (4). Bickerton and Buckley (5) have described two elements in the pressor response to angiotensin II : a centrally mediated effect, due to stimulation of central autonomic nervous structures, and a peripheral action on the vascular smooth muscle.

Angiotensin II is not only influenced in its vascular activity by the autonomic nervous system, but itself will release or enhance the response to stimuli releasing catecholamines. Thus, angiotensin II has been reported to enhance the pressor response to tyramine (6), to release catecholamines from the adrenal medulla ( 7$)$, and to lower the threshold to sympathetic nerve stimulation (8).

Renal ischemia was observed in this laboratory to alter the renal vascular response to angiotensin II. While examining the role of the nervous system in the production of this effect, renal denervation was observed to produce a loss of the renal

\footnotetext{
* Submitted for publication February 25, 1965 ; accepted August 5, 1965.

Abstracts of this paper appeared in Circulation 1964, 30, 124, and Clin. Res. 1965, 13, 214. Presented in part before the American Heart Association, October 1964.

Supported by grants HE-08805 and HE-5239, general research support grant 1S01-FR05115-01, and training grant T5-GM-4-07 from the U.S. Public Health Service.

$\dagger$ Established Investigator, American Heart Association (July 1, 1964).

Address requests for reprints to Dr. John C. McGiff, Dept. of Pharmacology, School of Medicine, University of Pennsylvania, Philadelphia, Pa. 19104.
}

vasoconstrictor activity of angiotensin II, similar to that produced by renal ischemia (9). The present study reports on the role of the nervous system in determining the renal vascular reactivity to angiotensin II. The renal vascular bed was selected for this study because it is the most sensitive of the regional beds tested to the vasoconstrictor effect of angiotensin II (10). Blockade by autonomic drugs of the renal vasoconstriction produced by angiotensin II was demonstrated. Autonomic blocking agents selected were representative of several classes: ganglionic blockade (hexamethonium), alteration of the release of the neurotransmitter by either central (hydralazine) or peripheral activity (guanethidine and bretylium), depletion of the transmitter (reserpine), and receptor blockade (phentolamine). The capacity of autonomic blocking agents to oppose the effects of angiotensin II was related to the activity of the drug at the neuroeffector site. Those blocking agents that reduced the release or depleted the neurotransmitter were demonstrated to oppose the renal vascular activity of angiotensin II.

\section{Methods}

Dogs weighing 21 to $32 \mathrm{~kg}$ (mean, $24 \mathrm{~kg}$ ) were anesthetized with morphine sulfate $(2 \mathrm{mg}$ per $\mathrm{kg}$, subcutaneously) and chloralose (70 $\mathrm{mg}$ per $\mathrm{kg}$, intravenously). Heparin 1 (200 to 400 International $U$ per $\mathrm{kg}$ ) was administered intravenously as the anticoagulant. The lungs were ventilated by a Starling Ideal pump through a $Y$-shaped glass tube inserted in the trachea.

A Sanborn multichannel direct writer recorded mean arterial pressure and the venous outflow of one kidney. In one experiment the two renal blood flows were measured simultaneously. The renal vein was cannulated with a plastic cannula (4 mm, inside diameter). The time required for cannulation, during which the arterial supply was interrupted by a clamp, was less than 2 minutes. The effluent was passed through a Shipley-Wilson ro-

1 Panheprin, Abbott Laboratories, North Chicago, Ill. 
tameter $(200 \mathrm{ml})$ that was placed below the cannulated vein. A common reservoir received the renal blood flow, which was returned to the femoral vein by a Sigmamotor pump, automatically activated when $40 \mathrm{ml}$ of blood was emptied into the reservoir. The amount of blood in the extracorporeal recording circuit was constant. The dead space of the recording system was $120 \mathrm{ml}$; an equal volume of plasma expander ( $6 \%$ gelatin solution) was used to prime this system.

In five experiments, acute denervation of the kidney was accomplished by transection of the renal artery. The denervated kidney was then perfused with blood from the carotid artery through a cannula inserted into the distal end of the sectioned renal artery.

In four experiments the first cervical vertebra was exposed and a laminectomy was performed. A 2-cm segment of spinal cord was uncovered by removing the overlying dura mater. After the renal vascular responses to the drugs were observed, the cord was transected.

The following drugs were administered intravenously: angiotensin $\mathrm{II}^{2}$ ( 0.1 to $0.5 \mu \mathrm{g}$ per $\mathrm{kg}$ ), tyramine hydrochloride ( 50 to $500 \mu \mathrm{g}$ per $\mathrm{kg}$ ), levarterenol bitartrate $(0.25$ to $2.0 \mu \mathrm{g}$ per $\mathrm{kg}$ ), epinephrine bitartrate ( 0.4 to $2.0 \mu \mathrm{g}$ per $\mathrm{kg})$, phentolamine methanesulfonate $(0.1 \mathrm{mg}$ per $\mathrm{kg}$ ), guanethidine sulfate ( 5 to $10 \mathrm{mg}$ per $\mathrm{kg}$ ), bretylium tosylate $(5 \mathrm{mg}$ per $\mathrm{kg}$ ), hexamethonium bromide ( 5 to $10 \mathrm{mg}$ per $\mathrm{kg}$ ), nicotinic acid tartrate (30 to $100 \mu \mathrm{g}$ per $\mathrm{kg}$ ), and hydralazine hydrochloride ( $2 \mathrm{mg}$ per $\mathrm{kg}$ ). In several experiments intravenous infusions of epi-

${ }^{2}$ Hypertensin, Ciba Pharmaceutical Co., Summit, N. J. nephrine and levarterenol ( 2 to $5 \mu \mathrm{g}$ per $\mathrm{kg}$ per minute) were administered. The doses of hexamethonium, tyramine, and hydralazine are given in terms of the salt; for the other drugs, doses are expressed as the base. Intravenous injections were made rapidly through a cannulated femoral vein in a fluid volume of less than $2 \mathrm{ml}$. In the experiments in which the kidney was denervated, renal intra-arterial injections were made possible; $1 \mathrm{ml}$ of the drug in appropriate concentration was administered into the cannula and tubing conducting the blood to the perfused kidney. Several schedules of reserpine ${ }^{3}$ administration were elected, for a usual dose of reserpine (e.g., $0.1 \mathrm{mg}$ per $\mathrm{kg}$ per day intramuscularly for 2 days) proved insufficient in two experiments to alter the renal vascular activity of angiotensin II. The dose of reserpine that effectively modified the renal vascular response to angiotensin II in four dogs was $0.1 \mathrm{mg}$ per $\mathrm{kg}$ intramuscularly, daily for 4 days, then $1 \mathrm{mg}$ per $\mathrm{kg}$ intravenously, 24 hours and 12 hours before the experiment.

To exclude tachyphylaxis or a time trend as a cause of the modified renal vascular response to angiotensin II, the following precautions were observed. a) In the control periods, i.e., before renal denervation, angiotensin II was administered only once. The only exception was that before spinal cord transection there were two injections of angiotensin II separated by an interval of 5 minutes. b) Successive injections of angiotensin II were separated by an interval of at least 3 minutes, which was deter-

${ }^{3}$ Serpasil phosphate, Ciba Pharmaceutical Co., Summit, N. J.

TABLE I

The renal vascular activity of angiotensin II as modified by acute denervation of the kidney (summary of five experiments)

\begin{tabular}{|c|c|c|c|}
\hline & $\begin{array}{l}\text { Blood pressure* } \\
\pm \mathrm{SE} \text { of mean }\end{array}$ & $\begin{array}{l}\text { Renal blood flow* } \\
\pm \mathrm{SE} \text { of mean }\end{array}$ & $\begin{array}{l}\text { Mean change } \\
\text { of renal blood } \\
\text { flow from con- } \\
\text { trolt } \pm \text { SE of } \\
\text { mean difference }\end{array}$ \\
\hline Predenervation & $m m \mathrm{Hg}$ & $m l / \min$ & $m l / m i n$ \\
\hline $\begin{array}{l}\text { Controlf } \\
\text { Angiotensin, iv, } 0.1 \mu \mathrm{g} / \mathrm{kg}\end{array}$ & $\begin{array}{l}116 \pm 14 \ddagger \\
165 \pm 12 \S\end{array}$ & $\begin{array}{l}175 \pm 18 \ddagger \\
135 \pm 20 \|\end{array}$ & $-42 \pm 10 \S$ \\
\hline $\begin{array}{l}\text { Control } \\
\text { Levarterenol, iv, } 1.0 \mu \mathrm{g} / \mathrm{kg}\end{array}$ & $\begin{array}{l}126 \pm 20 \\
171 \pm 19 \|\end{array}$ & $\begin{aligned} 170 & \pm 17 \\
94 & \pm 23 \|\end{aligned}$ & $-76 \pm 15$ \\
\hline $\begin{array}{l}\text { Postdenervation } \\
\text { Controlł } \\
\text { Angiotensin, iv, } 0.1 \mu \mathrm{g} / \mathrm{kg}\end{array}$ & $\begin{array}{r}95 \pm 7 \ddagger \\
144 \pm 11 \S\end{array}$ & $\begin{array}{l}123 \pm 24 \ddagger \\
143 \pm 23 \S\end{array}$ & $+20 \pm 2 \S$ \\
\hline $\begin{array}{l}\text { Control } \\
\text { Levarterenol, iv, } 1.0 \mu \mathrm{g} / \mathrm{kg}\end{array}$ & $\begin{array}{r}91 \pm 12 \\
136 \pm 23\end{array}$ & $\begin{aligned} 145 & \pm 8 \\
62 & \pm 18\end{aligned}$ & $-80 \pm 15$ \\
\hline $\begin{array}{l}\text { Control } \\
\text { Angiotensin, renal intra-arterial, } 0.05 \mu \mathrm{g} / \mathrm{kg}\end{array}$ & $\begin{array}{l}95 \pm 11 \\
97 \pm 9\end{array}$ & $\begin{aligned} 115 & \pm 20 \\
58 & \pm 22 \S\end{aligned}$ & $-57 \pm 9$ \\
\hline
\end{tabular}

* The mean values of the renal blood flows and blood pressures resulting from administration of angiotensin II and levarterenol were compared with the mean of the control values. Differences were statistically evaluated; unless otherwise indicated $\mathrm{p}>0.05$.

$t$ The mean changes of renal blood flow from control resulting from intravenous administration of angiotensin II and levarterenol were compared before and after denervation of the kidney. Differences were statistically evaluated; unless otherwise indicated $\mathrm{p}>0.05$.

$\ddagger$ The mean values for the angiotensin control periods, pre- and postdenervation, did not differ significantly.

$\S p<0.01$.

$\| \mathrm{p}<0.05$. 

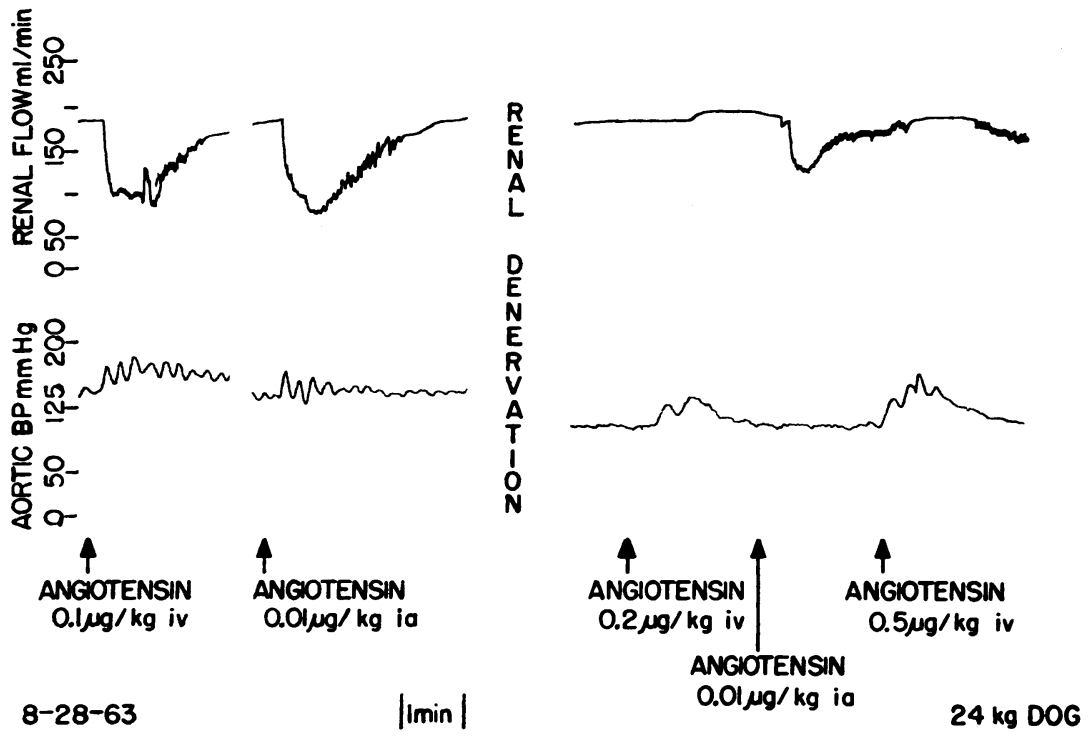

Fig. 1. EFFect of Renal Denervation on the RENAL VASCUlar RESPONSE to ANGIOTENSIN II IN A DOG UNDER MORPHINE-CHLORALOSE. Acute renal denervation abolished the constriction of the renal vasculature produced by angiotensin II intravenously and reduced the response to intra-arterial (ia) angiotensin II. Ten minutes elapsed between the left and right panels. $\mathrm{BP}=$ blood pressure.

mined by earlier work as an appropriate interval (9). c) The observations were confined to the first $90 \mathrm{~min}-$ utes after having set up the preparation, during which no appreciable time trend was observed $(9,11) . d)$ The renal vascular response to angiotensin II when altered was then compared to levarterenol or epinephrine to exclude the development of vascular refractoriness.

The results were expressed as the maximal change in renal blood flow, mean aortic blood pressure, and calculated vascular resistance elicited by the stimulus. Vascular resistances for the experimental period were determined by dividing the mean aortic blood pressure by the value expressed in milliliters per minute, representing the maximal change in renal blood flow produced by the stimulus. Statistical analyses were made on paired analyses of control and experimental values of the maximal change in renal blood flow and simultaneous blood pressure after application of the stimulus (12).

\section{Results}

\section{Acute renal denervation}

In five experiments, acute renal denervation resulted in a loss of the renal vasoconstrictor activity of angiotensin II ( $0.1 \mu \mathrm{g}$ per $\mathrm{kg})$ administered intravenously (Table I and Figure 1). After acute renal denervation, intravenous administration of $0.1 \mu \mathrm{g}$ per $\mathrm{kg}$ of angiotensin II increased renal blood flow in all cases $(20 \mathrm{ml}$ per minute, mean of five experiments), whereas the same dose of angiotensin II before denervation always resulted in a reduction of renal blood flow $(-42 \mathrm{ml}$ per minute) (Table I). After denervation, even a fivefold increase in the amount of intravenous angiotensin II failed to constrict the renal blood vessels (Figure 1 ). The mean change of renal blood flow elicited by intravenous levarterenol ( 1 $\mu \mathrm{g}$ per $\mathrm{kg}$ ) before and after renal denervation, of -76 and $-80 \mathrm{ml}$ per minute, respectively, did not differ significantly (Table I).

In all experiments in which the kidney was denervated, angiotensin II (Figure 1) administered into the renal artery $(0.01 \mu \mathrm{g}$ per $\mathrm{kg})$ continued to elicit renal vasoconstriction (Table I and Figure 1). In Figure 2 the effect of angiotensin II upon the renal blood flows measured simultaneously is shown after denervation of one kidney. Under these conditions, angiotensin II elicited a differential effect on renal blood flows; the blood flow to the denervated kidney increased in response to intravenous angiotensin II, whereas vasoconstriction occurred simultaneously in the innervated kidney.

\section{Spinal cord section}

In four experiments, nervous activity was modified by interrupting the autonomic nerve supply at 


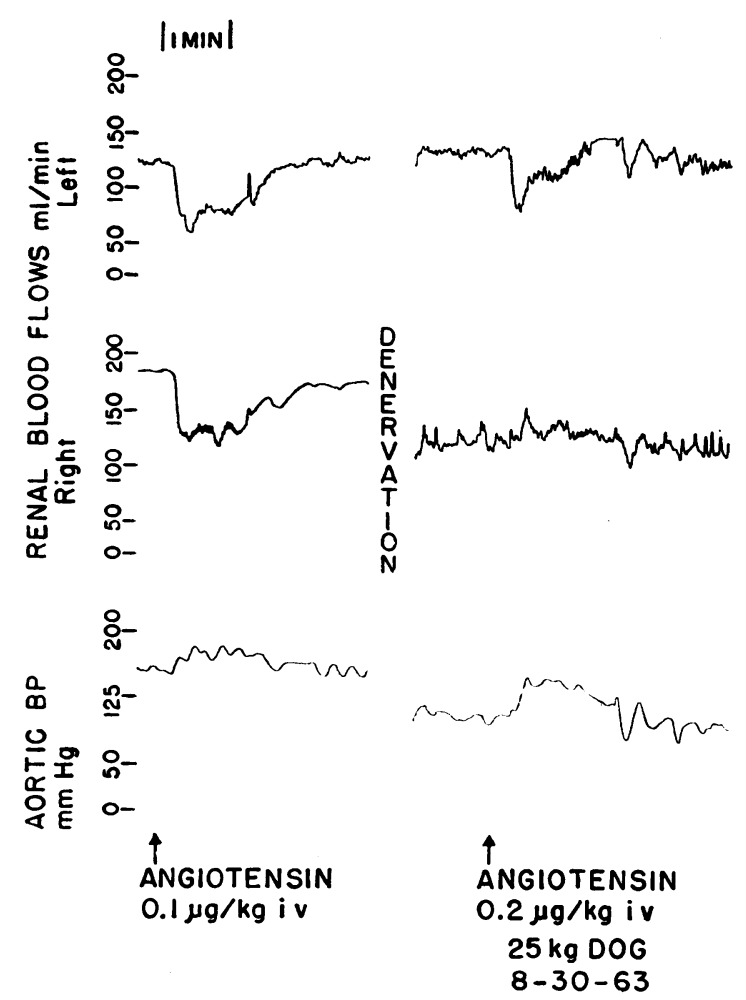

Fig. 2. Differential REaction of the Renal blood FLOWS TO ANGIOTENSIN II IN A DOG UNDER MORPHINECHLORALOSE. Between the left and right panels, the right kidney was denervated. Fifteen minutes separates the two panels.

the level of the spinal cord (Table II). The cervical cord was sectioned immediately after recording control observations of the response of the renal vasculature to angiotensin II. After cord section, elimination of the renal vasoconstrictor effect of angiotensin II administered intravenously was noted.

After cord section, angiotensin II $(0.1 \mu \mathrm{g}$ per $\mathrm{kg}$ ) administered intravenously increased the renal blood flow by $29 \mathrm{ml}$ per minute (mean of four experiments), whereas before cord section a reduction of $88 \mathrm{ml}$ per minute (mean of four experiments) was recorded ( $p<0.01$; Table II). The decreased reactivity of the renal vasculature to angiotensin II produced by cord section was not observed for catecholamines. An epinephrine infusion (4 $\mu \mathrm{g}$ per $\mathrm{kg}$ per minute) after cord section resulted in cessation of the renal blood flow. Levarterenol by intravenous injection $(1 \mu \mathrm{g}$ per $\mathrm{kg}$ ) as well as by infusion ( $5 \mu \mathrm{g}$ per $\mathrm{kg}$ per minute) increased renal vascular resistance by $220 \%$ and $604 \%$ of control values, respectively, after cord section.

\section{Autonomic blocking agents}

The effect of acute renal denervation and cord section on the renal vascular response to angiotensin II prompted the use of drugs that modify autonomic nervous activity. The selection of autonomic blocking agents was determined by their possessing major blocking activity at different sites, either prejunctionally, along the autonomic nerve and its central connections, or at the sympathetic receptor $(\alpha)$ that mediates renal vasoconstriction. Phentolamine was used to block the $\alpha$ receptors. The following drugs were used to in-

TABLE II

Renal vascular effects of angiotensin II before and after spinal cord transection (summary of four experiments)

\begin{tabular}{|c|c|c|c|}
\hline Procedure & $\begin{array}{l}\text { Blood pressure* } \\
\pm \mathrm{SE} \text { of mean }\end{array}$ & $\begin{array}{l}\text { Renal blood flow* } \\
\pm \text { SE of mean }\end{array}$ & $\begin{array}{l}\text { Mean change of } \\
\text { renal bloor flow } \\
\text { from controlf } \pm \text { SE } \\
\text { of mean di ference }\end{array}$ \\
\hline Before cord section & $m m \mathrm{Hg}$ & $m l / m i n$ & $m l / m i n$ \\
\hline $\begin{array}{l}\text { Control } \\
\text { Angiotensin, iv, } 0.1 \mu \mathrm{g} / \mathrm{kg}\end{array}$ & $\begin{array}{l}135 \pm 13 \\
180 \pm 17 \ddagger\end{array}$ & $\begin{aligned} 176 & \pm 11 \\
89 & \pm 15 \S\end{aligned}$ & $-88 \pm 17 \ddagger$ \\
\hline $\begin{array}{l}\text { After cord section } \\
\text { Control } \\
\text { Angiotensin, iv, } 0.1 \mu \mathrm{g} / \mathrm{kg}\end{array}$ & $\begin{aligned} 84 & \pm 6 \\
111 & \pm 7 \ddagger\end{aligned}$ & $\begin{array}{l}106 \pm 8 \\
135 \pm 12\end{array}$ & $+29 \pm 10 \ddagger$ \\
\hline
\end{tabular}

* The mean values of the blood pressures and renal blood flows produced by angiotensin II were compared with the mean values of the control blood pressures and renal blood flows. Differences were statistically evaluated.

$\dagger$ The mean changes of renal blood flow from control resulting from administration of angiotensin II, before and after cord transection, were significantly different from each other.

$\ddagger \mathrm{p}<0.01$.

$\$ \mathrm{p}<0.05$. 
TABLE III

The effect of guanethidine upon the renal vascular activity of angiotensin II

\begin{tabular}{|c|c|c|c|c|}
\hline & & $\begin{array}{c}\text { Blood } \\
\text { pressure }\end{array}$ & $\begin{array}{l}\text { Renal } \\
\text { blood } \\
\text { flow }\end{array}$ & $\begin{array}{c}\text { Renal } \\
\text { vascular } \\
\text { resistance }\end{array}$ \\
\hline $\operatorname{Dog} 1$ & $\begin{array}{l}\text { Control } \\
\text { Angiotensin, iv, } 0.1 \mu \mathrm{g} / \mathrm{kg}\end{array}$ & $\begin{array}{c}m m \mathrm{Hg} \\
95 \\
155\end{array}$ & $\begin{array}{l}m l / \min \\
190 \\
100\end{array}$ & $\begin{array}{r}\% \Delta \\
+210\end{array}$ \\
\hline & $\begin{array}{l}\text { Guanethidine, iv, } 10 \mathrm{mg} / \mathrm{kg} \\
\text { Control } \\
\text { Angiotensin, iv, } 0.1 \mu \mathrm{g} / \mathrm{kg}\end{array}$ & $\begin{array}{l}150 \\
165\end{array}$ & $\begin{array}{l}200 \\
200\end{array}$ & +11 \\
\hline $\operatorname{Dog} 2$ & $\begin{array}{l}\text { Control } \\
\text { Angiotensin, iv, } 0.2 \mu \mathrm{g} / \mathrm{kg}\end{array}$ & $\begin{array}{r}80 \\
110\end{array}$ & $\begin{array}{l}195 \\
160\end{array}$ & +68 \\
\hline & $\begin{array}{l}\text { Guanethidine, iv, } 10 \mathrm{mg} / \mathrm{kg} \\
\text { Control } \\
\text { Angiotensin, iv, } 0.2 \mu \mathrm{g} / \mathrm{kg}\end{array}$ & $\begin{array}{r}90 \\
110\end{array}$ & $\begin{array}{l}210 \\
210\end{array}$ & +21 \\
\hline $\operatorname{Dog} 3$ & $\begin{array}{l}\text { Control } \\
\text { Angiotensin, iv, } 0.1 \mu \mathrm{g} / \mathrm{kg}\end{array}$ & $\begin{array}{l}140 \\
185\end{array}$ & $\begin{array}{l}170 \\
110\end{array}$ & +105 \\
\hline & $\begin{array}{l}\text { Guanethidine, iv, } 10 \mathrm{mg} / \mathrm{kg} \\
\text { Control } \\
\text { Angiotensin, iv, } 0.1 \mu \mathrm{g} / \mathrm{kg}\end{array}$ & $\begin{array}{l}115 \\
145\end{array}$ & $\begin{array}{l}130 \\
145\end{array}$ & +14 \\
\hline Dog 4 & $\begin{array}{l}\text { Hexamethonium, iv, } 10 \mathrm{mg} / \mathrm{kg} \\
\text { (administered } 20 \text { minutes previously) } \\
\text { Control } \\
\text { Angiotensin, iv, } 0.1 \mu \mathrm{g} / \mathrm{kg}\end{array}$ & $\begin{array}{l}45 \\
85\end{array}$ & $\begin{array}{r}150 \\
55\end{array}$ & +413 \\
\hline & $\begin{array}{l}\text { Guanethidine, iv, } 8 \mathrm{mg} / \mathrm{kg} \\
\text { Control } \\
\text { Angiotensin, iv, } 0.1 \mu \mathrm{g} / \mathrm{kg}\end{array}$ & $\begin{array}{l}110 \\
140\end{array}$ & $\begin{array}{l}125 \\
140\end{array}$ & +14 \\
\hline
\end{tabular}

terrupt autonomic nervous activity: hydralazine (central effect), hexamethonium (ganglionic blockade), guanethidine and bretylium (modification of the release of the autonomic neurotransmitter), and reserpine (depletion of the neurotransmitter). In most cases the renal vascular effects of angiotensin II and levarterenol were compared before and after administration of the blocking agent. Because of the duration of activity of the autonomic blocking drugs, a single set of observations for one drug was made per experiment. No animal received more than one blocking agent except for the use of guanethidine after hexamethonium (Table III) in one experiment.

Phentolamine and hexamethonium. Phentolamine ( $0.1 \mathrm{mg}$ per $\mathrm{kg}$, intravenously) and hexamethonium ( 5 to $10 \mathrm{mg}$ per $\mathrm{kg}$, intravenously) failed to block the renal vasoconstriction elicited by angiotensin II (Figures 3 and 4, Table IV). In Figure 3, the vasoconstrictor activity of angiotensin II and levarterenol after drug intervention is expressed in terms of their per cent change from control values. Thus before phentolamine, angiotensin II administered intravenously increased renal vascular resistance by $117 \%$ and $105 \%$; after phentolamine a $160 \%$ and $81 \%$ increase, respectively, in renal vascular resistance was produced by angiotensin II. The differences (Figure 3 ) of $+37 \%$ and $-23 \%$ between the per cent increase of renal vascular resistance angiotensin II produced before and after drug intervention were not significant. To be significant $(p<0.05)$ a greater than $62 \%$ reduction in the renal vasoconstrictor effect of angiotensin II or levarterenol, after the administration of the blocking drug, was required (Symbols falling below the broken line in Figure 3 represent significant reductions by the blocking drug of the renal vasoconstriction produced by the pressor agent). As expected, phentolamine $(0.1 \mathrm{mg}$ per $\mathrm{kg}$, intravenously) in two experiments did block the renal vasoconstriction produced by levarterenol (Figure 3), whereas the renal vascular effects of levarterenol were not reduced by hexamethonium. In four dogs that had received hexamethonium ( $\mathrm{Ta}$ ble IV), $0.1 \mu \mathrm{g}$ per $\mathrm{kg}$ of angiotensin II intrave- 


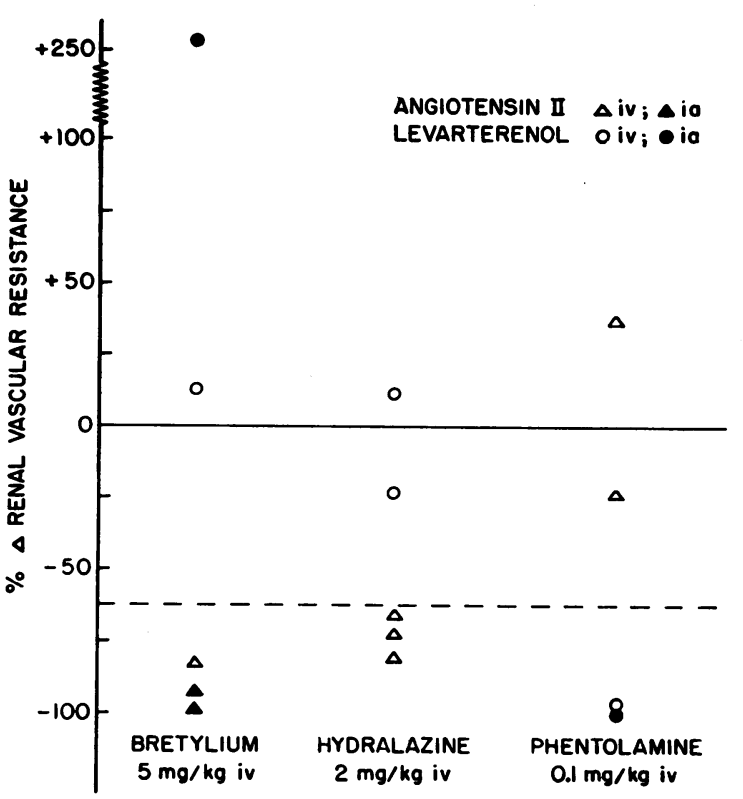

Fig. 3. EFFECt OF AUTONOMIC BLOCKING DRUGS ON THE RENAL VASCULAR RESPONSE TO ANGIOTENSIN II AND LEVARTERENOL. The circles (levarterenol) and triangles (angiotensin II) represent the difference expressed as per cent change $(\% \Delta)$ between two observations: the per cent increase in renal vascular resistance produced by the pressor agent before and after drug intervention. Each triangle represents a single experiment. Of the eight experiments depicted here, levarterenol was administered also in six. Angiotensin was used in $0.1 \mu \mathrm{g}$ per $\mathrm{kg}$ doses iv and $0.05 \mu \mathrm{g}$ per $\mathrm{kg}$ ia (renal artery), levarterenol $1.0 \mu \mathrm{g}$ per $\mathrm{kg}$ iv and $0.5 \mu \mathrm{g}$ per $\mathrm{kg}$ ia. Significant reduction of the renal vascular response to angiotensin II or levarterenol $(p<0.05)$ by the blocking agent occurred when the symbol falls below the broken line. Thus bretylium and hydralazine altered significantly the renal vascular response to angiotensin II, whereas phentolamine modified that to levarterenol.
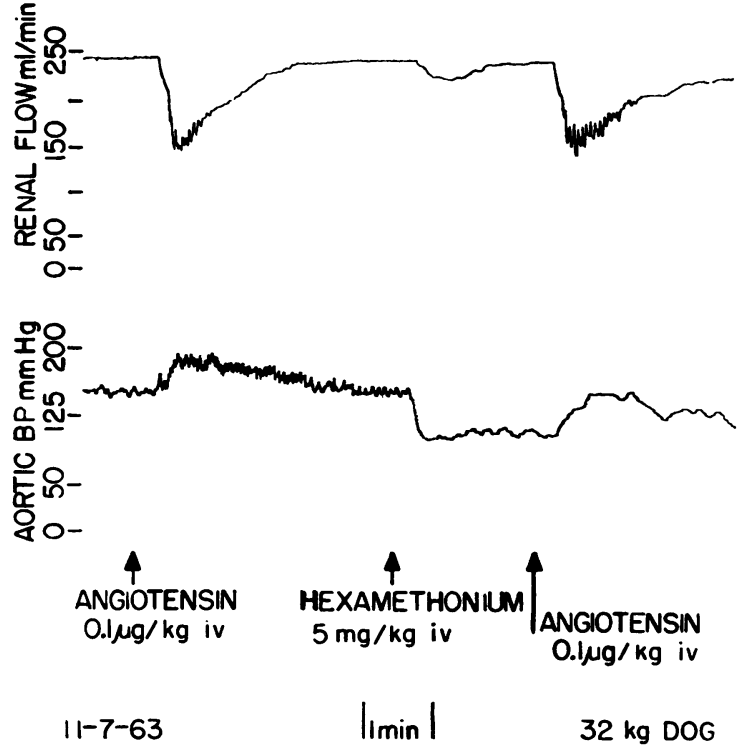

Fig. 4. THE EFFECT OF HEXAMETHONIUM ON THE RENAL VASCULAR RESPONSE TO ANGIOTENSIN II IN A DOG UNDER MORPHINE-CHLORALOSE.

nously produced a mean increase in renal vascular resistance of $194 \%$, which did not differ significantly $(p>0.05)$ from the mean change in renal vascular resistance that angiotensin II elicited before hexamethonium, $+172 \%$. The control mean blood pressure of $74 \mathrm{~mm} \mathrm{Hg}$ after hexamethonium, when contrasted to that before hexamethonium of $140 \mathrm{~mm} \mathrm{Hg}$ (Table IV), testifies to the adequacy of the dosage of hexamethonium.

Guanethidine, bretylium, and hydralazine. Guanethidine ( 5 to $10 \mathrm{mg}$ per $\mathrm{kg}$ ) administered intravenously abolished or reduced markedly the

TABLE IV

The effect of hexamethonium upon the renal vascular response to angiotensin II (summary of four experiments)

\begin{tabular}{|c|c|c|c|}
\hline & $\begin{array}{l}\text { Blood pressure* } \\
\pm \text { SE of mean }\end{array}$ & $\begin{array}{l}\text { Renal blood flow* } \\
\pm \mathrm{SE} \text { of mean }\end{array}$ & $\begin{array}{l}\text { Renal vascular } \\
\text { resistancet } \\
\pm \mathrm{SE} \text { of mean }\end{array}$ \\
\hline $\begin{array}{l}\text { Control } \\
\text { Angiotensin, iv, } 0.1 \mu \mathrm{g} / \mathrm{kg}\end{array}$ & $\begin{array}{l}m m \mathrm{Hg} \\
140 \pm 7 \\
180 \pm 6 \ddagger\end{array}$ & $\begin{array}{l}m l / m i n \\
201 \pm 14 \\
118 \pm 26 \S\end{array}$ & $\begin{array}{c}\% \text { change } \\
+172 \pm 79 \dagger\end{array}$ \\
\hline $\begin{array}{l}\text { Hexamethonium, iv, } 5-10 \mathrm{mg} / \mathrm{kg} \\
\text { Control } \\
\text { Angiotensin, iv, } 0.1 \mu \mathrm{g} / \mathrm{kg}\end{array}$ & $\begin{array}{c}74 \pm 10 \\
121 \pm 13 \ddagger\end{array}$ & $\begin{array}{l}184 \pm 13 \\
121 \pm 22 \S\end{array}$ & $+194 \pm 75 \dagger$ \\
\hline
\end{tabular}

* The mean values of the renal blood flows and blood pressures resulting from intravenous administration of angiotensin II were compared with the mean of the control values. Differences were statistically evaluated.

$\dagger$ The mean values for the per cent change in renal vascular resistance elicited by angiotensin II before and after hexamethonium were compared. The differences were not significantly different, $\mathrm{p}>0.05$.

$\ddagger \mathrm{p}<0.01$.

$\S \mathrm{p}<0.05$ 


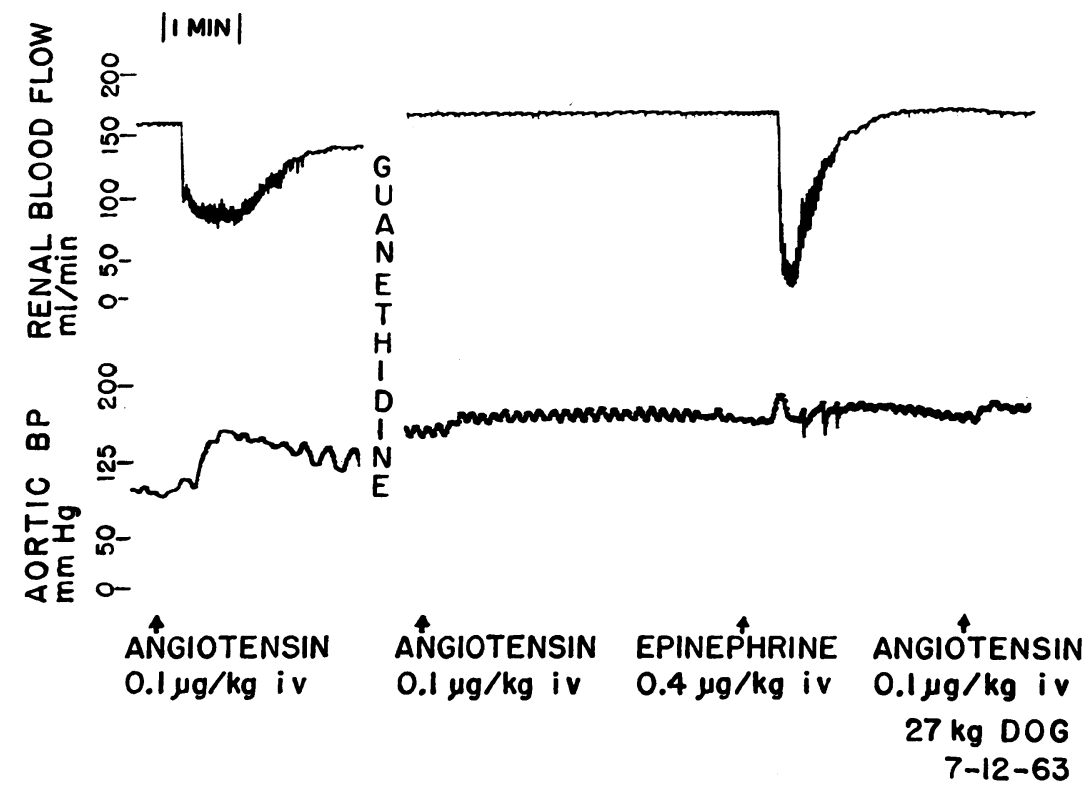

Fig. 5. Guanethidine blockade of the RENAL vasoconstrictor activity of ANGIOTENSIN II IN A DOG UNDER MORPHINE-CHLORALOSE. The two panels are separated by 5 minutes, during which guanethidine, $10 \mathrm{mg}$ per $\mathrm{kg}$, was administered intravenously.

renal vasoconstrictor activity of intravenous angiotensin II in four dogs (Table III and Figure 5), whereas the renal vascular effects of catecholamines were unimpaired. This effect was rapid in onset (within 20 seconds of guanethidine administration, intravenously), was reversed by tyramine, and was more effective than acute renal denervation. Thus acute renal denervation did not abolish the renal vasoconstriction elicited by angiotensin II administered into the renal artery (Table I), whereas guanethidine $(5 \mathrm{mg}$ intra-arterially or 5 to $10 \mathrm{mg}$ per $\mathrm{kg}$ intravenously) eliminated or markedly reduced the renal vascular activity of angiotensin II administered intra-arterially as well (Figure 6). The blockade of the vascular activity of angiotensin II by guanethidine was unrelated to the degree of pre-existing vascular tone, for it was seen at control blood pressures as disparate as 45 $\mathrm{mm} \mathrm{Hg}$ (posthexamethonium) and $150 \mathrm{~mm} \mathrm{Hg}$ (Table III). The pressor effect of angiotensin II administered intravenously was not eliminated by guanethidine.

In three animals each, bretylium ( $5 \mathrm{mg}$ per $\mathrm{kg}$ ) and hydralazine ( $2 \mathrm{mg}$ per $\mathrm{kg}$ ) also opposed the renal vascular activity of angiotensin II (Figure 3 ), for the drug-induced reduction in the renal vascular resistance produced by angiotensin II was in each case greater than $62 \%$ of control $(p<$ $0.05)$. The renal vascular effect of levarterenol (1 $\mu \mathrm{g}$ per $\mathrm{kg}$ ) was not reduced significantly by either hydralazine or bretylium (Figure 3 ).

Tyramine and renal vascular reactivity. The ability of guanethidine or bretylium to abolish the response to angiotensin II administered intra-arterially was compromised by previous administration of tyramine. The administration of tyramine (100 to $500 \mu \mathrm{g}$ per $\mathrm{kg}$ ) restored the renal vascular activity of angiotensin II after that activity had been blocked by guanethidine (Figure 6). After spinal cord section, the vasoconstrictor effects of angiotensin II were abolished; however, after administration of tyramine ( 50 to $200 \mu \mathrm{g}$ per $\mathrm{kg}$ ), partial restoration of the renal vascular effect of angiotensin II was possible. It should be noted, however, that there are forms of altered renal vascular reactivity to angiotensin II that tyramine will not restore, e.g., that produced by reserpine.

Reserpine. The results thus far suggest a relationship between autonomic nervous activity and the vascular action of angiotensin II. Reserpine was administered in six dogs in an attempt to modify the renal vascular response to angiotensin 


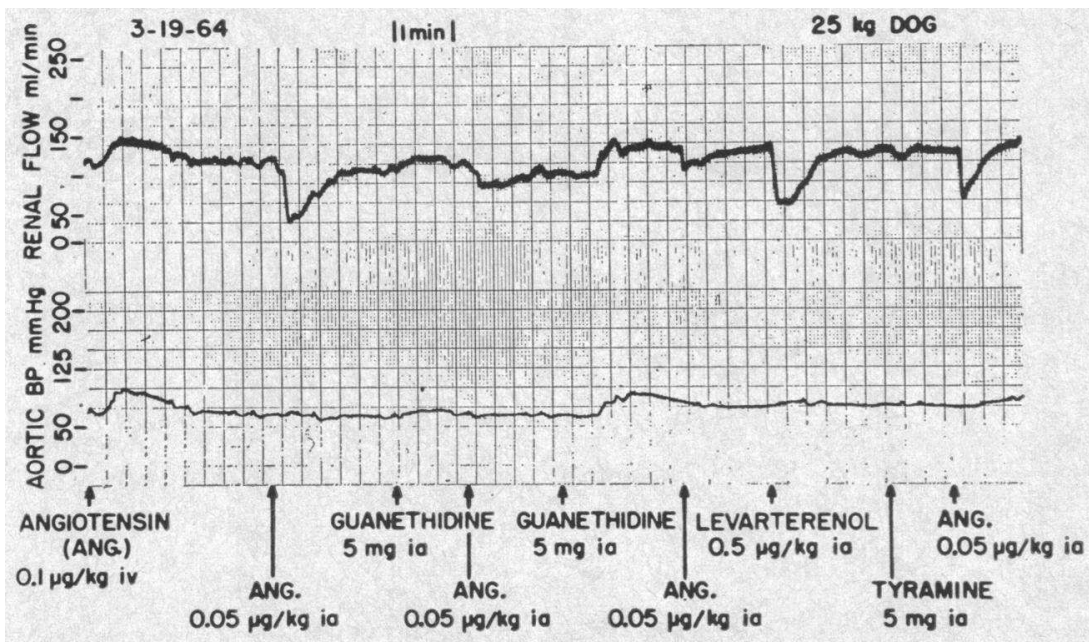

Fig. 6. BLOCKAdE AND RESTORATION OF THE RENAL VASCULAR RESPONSE to ANGIOTENSIN II IN A DOG UNDER MORPHINE-CHLORALOSE. Thirty minutes previously the kidney was denervated acutely. The renal vascular response to angiotensin II injected into the renal artery was blocked by guanethidine and restored by tyramine.

II. In four animals receiving reserpine, the results of which are presented in Table $\mathrm{V}$, angiotensin II ( $0.1 \mu \mathrm{g}$ per $\mathrm{kg}$, intravenously) produced changes in renal vascular resistance of $+14 \%$ (mean of four experiments) that were significantly different $(\mathrm{p}<0.05)$ from the mean values $(+247)$ produced by angiotensin II in the four animals not receiving reserpine. In two dogs receiving smaller doses of reserpine (see Methods) there was no reduction in the renal vasoconstrictor effect of angiotensin II. In the four dogs given reserpine that demonstrated a reduced renal vascular response to angiotensin II, levarterenol (1 $\mu \mathrm{g}$ per $\mathrm{kg}$, intravenously) increased renal vascular resistance by $303 \%, 250 \%, 577 \%$, and $330 \%$ of control, which were not significantly different ( $p>0.05$ ) from the increase in renal vascular resistance produced by levarterenol in dogs that did not receive reserpine $(368 \pm 95 \%)$.

To evaluate the completeness of depletion of catecholamines, intravenous nicotine (30 to 100 $\mu \mathrm{g}$ per $\mathrm{kg}$ ) was used. Nicotine has been demonstrated in this preparation (13) to be one of the most potent releasers of catecholamines; e.g., 50 $\mu \mathrm{g}$ per $\mathrm{kg}$ of nicotine administered intravenously increased renal vascular resistance by $373 \%$ and

TABLE V

The effect of reserpine upon the renal vascular activity of angiotensin II (summary of eight experiments)

\begin{tabular}{|c|c|c|c|}
\hline & $\begin{array}{l}\text { Blood pressure* } \\
\pm \mathrm{SE} \text { of mean }\end{array}$ & $\begin{array}{l}\text { Renal blood flow* } \\
\pm S E \text { of mean }\end{array}$ & $\begin{array}{l}\text { Renal vascular } \\
\text { resistance } \\
\pm \mathrm{SE} \text { of mean }\end{array}$ \\
\hline & $m m \mathrm{Hg}$ & $\mathrm{ml} / \mathrm{min}$ & \% change \\
\hline $\begin{array}{l}\text { Without reserpine (4 dogs) } \\
\text { Control } \\
\text { Angiotensin, iv, } 0.1 \mu \mathrm{g} / \mathrm{kg}\end{array}$ & $\begin{array}{l}144 \pm 13 \\
201 \pm 9 *\end{array}$ & $\begin{array}{r}153 \pm 8 \\
73 \pm 20^{*}\end{array}$ & $+247 \pm 63 \dagger$ \\
\hline $\begin{array}{l}\text { Reserpine ( } 4 \text { dogs) } \\
\text { Control } \\
\text { Angiotensin, iv, } 0.1 \mu \mathrm{g} / \mathrm{kg}\end{array}$ & $\begin{array}{l}62 \pm 2 \\
81 \pm 7\end{array}$ & $\begin{array}{l}119 \pm 14 \\
136 \pm 11\end{array}$ & $+14 \pm 3 \dagger$ \\
\hline
\end{tabular}

* The mean values of the blood pressures and renal blood flows produced by angiotensin II in dogs with and without reserpine were compared with the mean values of the control blood pressures and renal blood flows. Differences were statistically evaluated; $p<0.05$.

† The per cent change of control in renal vascular resistances produced by angiotensin II in dogs with and without reserpine was statistically evaluated for significant differences; $p<0.05$. 
$396 \%$ of control. A parallel effect on the renal vascular bed was observed for nicotine and angiotensin II. When the renal vascular response to nicotine was eliminated or reduced, a similar response to angiotensin II was observed.

The relationship between the renal vascular effects of nicotine and angiotensin II was expressed in several ways. The effect of angiotensin II on the renal vasculature was usually predicted by the response of the renal vascular bed to nicotine. A relationship between nicotine and angiotensin II in terms of an available tissue store of catecholamines was suggested further by a reduced capacity of angiotensin II to elicit renal vasoconstriction when administered shortly after nicotine (Figure 7). Furthermore, in the reserpine treated dog, exhaustion by repeated intravenous injections of nicotine ( $50 \mu \mathrm{g}$ per $\mathrm{kg}$ ) of an already partially depleted sympathetic neurotransmitter store resulted in a loss of the renal vasoconstrictor activity of angiotensin II, coincident with the loss of the renal vascular effect of nicotine.

In the animals receiving reserpine, restoration of the renal vascular response to angiotensin II was not accomplished by tyramine (100 to $300 \mu \mathrm{g}$ per $\mathrm{kg}$ ). In these reserpine treated animals, administration of as small an amount of levarterenol as $0.25 \mu \mathrm{g}$ per $\mathrm{kg}$ resulted in a partial restoration of the renal vascular reactivity to angiotensin II administered intravenously. Thus, the renal blood flow, which previously was unchanged by angio-

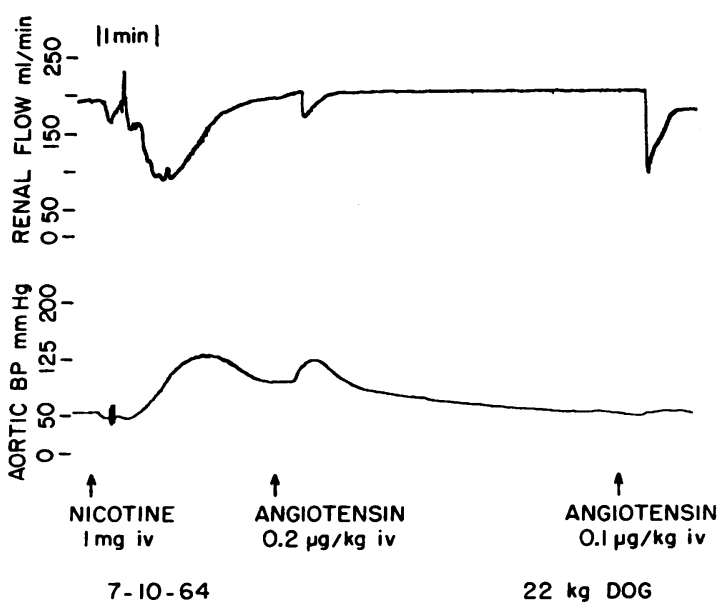

Fig. 7. The alteration of the Renal vascular aCTIVITY OF ANGIOTENSIN II BY NICOTINE IN A DOG UNDER MORPHINE-CHLORALOSE. tensin II, was reduced by $22 \%, 12 \%, 13 \%$, and $35 \%$ of control by intravenous angiotensin II ( 0.1 $\mu \mathrm{g}$ per $\mathrm{kg}$ ) after levarterenol administration in the reserpine treated dogs. Simultaneously, levarterenol restored partially the renal vascular response to nicotine ( $50 \mu \mathrm{g}$ per $\mathrm{kg}$, intravenously).

\section{Discussion}

The renal vascular activity of angiotensin II has been demonstrated in the present experiments to be related closely to the autonomic nervous system. Thus, the vascular action of angiotensin II is opposed by those agents whose primary effect is on the sympathetic postganglionic fiber (bretylium and guanethidine) (14) or by agents that alter sympathetic activity by a central action (hydralazine) (15). Those autonomic blocking agents that do not interfere with release of the sympathetic neurotransmitter, e.g., hexamethonium (16), or have a primary effect at the sympathetic $\alpha$ receptor site (phentolamine) (17) will not block the renal vascular activity of angiotensin II. A more precise definition of this relationship may be made only conditionally. For example, the vascular activity of angiotensin II may have a cholinergic determinant. Thus, the stimulation by angiotensin II of the isolated intestines has been reported to depend on the release of acetylcholine, since the response is abolished by depleting actetylcholine and is potentiated by anticholinesterases $(18,19)$. A cholinergic link for sympathetic nervous activity has been proposed $(20,21)$. According to Burn and Rand, acetylcholine liberated by the adrenergic nerve impulse releases catecholamines. Whether or not a cholinergic mechanism is involved in the vascular activity of angiotensin II cannot be stated from the evidence provided by the present experiments.

Bretylium and guanethidine, which have been reported to block sympathetic nervous activity, opposed the renal vascular activity of angiotensin II (Figures 3 and 5). It would be premature, however, to adduce this as evidence of the dependency of the vascular activity of angiotensin II upon the sympathetic neurotransmitter, for bretylium and guanethidine may have a primary anticholinergic effect. Thus, Bhagat showed that the activity of guanethidine upon catecholamine stores of the rat ventricle was prevented by hemicholinium, which 
inhibits acetylcholine synthesis (22). Bhagat further demonstrated that administration of choline chloride, which promotes acetylcholine synthesis, will restore the capacity of guanethidine to deplete catecholamines from subcellular fractions. Bretylium has been suggested by Burn and Froede to have anticholinergic activity (23). With these qualifications in mind, a tentative construction of the relationship between angiotensin II and the autonomic nervous system will be attempted.

The effects of acute renal denervation upon the renal vascular activity of angiotensin II suggested at least two elements in the renal vascular response. After renal denervation, the renal vascular effect of angiotensin II administered intravenously was eliminated, whereas renal intra-arterial injection of angiotensin II continued to elicit renal vasoconstriction. These observations agree with those of Laverty (3) and Zimmerman (4). Laverty demonstrated that the vasoconstriction of the rat hind limb elicited by intravenous angiotensin II was immediately abolished by denervation of the limb. Zimmerman showed in the dog that after acute sympathectomy of the hindquarter, the vasoconstrictor response to intra-arterial administration of angiotensin II was reduced. A bimodal mechanism of the action of angiotensin II, one nerve mediated and the other direct, has been postulated by Benelli, Della Bella, and Gandini (8). In cross-perfusion experiments in dogs, Bickerton and Buckley (5) described a central hypertensive effect of angiotensin II that was blocked peripherally by an adrenergic blocking agent, piperoxan. In the present experiments, the effects of cervical cord transection upon the renal vascular activity of angiotensin II administered intravenously suggest the importance of central nervous activity in the fully developed renal vascular response to angiotensin II.

The failure of hexamethonium to alter the renal vascular response to angiotensin II would appear to exclude a central nervous mechanism in the renal vascular response to angiotensin II administered intravenously. However, hexamethonium has been reported to be ineffective in the blockade of the pressor response to some sympathetic ganglionic stimulants, whereas atropine will block this pressor response (24). Hertting, Potter, and Axelrod showed that hexamethonium failed to reduce, or only slightly reduced, the spontaneous re- lease of levarterenol- ${ }^{3} \mathrm{H}$ from the rat heart, which release is an index of transmission of impulses in postganglionic fibers (16). In the same preparation, on the other hand, bretylium reduced the release of levarterenol $-{ }^{3} \mathrm{H}$, which is consistent with the presumed effect of bretylium on sympathetic nerve transmission and the renal vascular response to angiotensin II. In addition, Robertson and Rubin (18), using an isolated system, showed that hexamethonium did not block the contractile response of the guinea pig ileum to angiotensin II.

The present results suggest that the renal vascular effect of angiotensin II depends in part at least on the presence of catecholamines, for reserpine will reduce or abolish the reactivity of the renal vasculature to angiotensin II. A reduction of the vascular activity of angiotensin II in the hind limb of the dog has been reported after reserpine (25). In two of the present experiments, a schedule of reserpine administration that might be expected to reduce catecholamines to less than $10 \%$ of the control levels (26) failed to reduce the renal vasoconstrictor activity of angiotensin II. In all of the experiments in which reserpine was used, tyramine failed to elicit renal vasoconstriction. This observation confirms the near depletion of catecholamines effected by reserpine, for Crout, Muskus, and Trendelenburg have reported that in isolated guinea pig atria pretreated with reserpine, only $2 \%$ of the normal tissue catecholamines was required for tyramine to produce a response (27). Nicotine, the renal vasoconstrictor activity of which depends on the presence of local catecholamines, had effects similar to angiotensin II. In the four experiments in which the renal vascular effect of angiotensin II was abolished or reduced by reserpine, the renal vascular activity of nicotine was similarly attenuated. Furthermore, administration of angiotensin II directly after nicotine, after the return of renal blood flow to control levels, resulted in reduced vasoconstriction elicited by angiotensin II (Figure 7). These results suggest that nicotine and angiotensin II require an identical or similar store of the sympathetic neurotransmitter for their activity. This store is either affected by these agents directly or through a common intermediary of catecholamine release as acetylcholine. A parallel reduction of the effect of nicotine and angiotensin II on the contraction of the isolated ileum of the guinea pig 
and rabbit after depletion of acetylcholine has been observed by Robertson and Rubin (18).

Further evidence to support the participation of catecholamines in the renal vascular response to angiotensin II is provided by the effects of tyramine. After blockade of the renal vascular effects of angiotensin II by guanethidine or section of the spinal cord, tyramine restored the reactivity of the renal vasculature to angiotensin II. Tyramine will not restore the renal vascular activity of angiotensin II after depletion of catecholamines by reserpine. Several lines of evidence relating to the effects of tyramine (or other indirect acting sympathomimetic amines) and guanethidine converge on the autonomic nervous mechanism, which releases the sympathetic neurotransmitter. Guanethidine has been reported to block the pressor effect and the development of tension in isolated atria of rats induced by tyramine, in the absence of any significant reduction of tissue catecholamines (28). Bhagat has suggested that guanethidine and tyramine act on the same store of levarterenol; a competitive antagonism between guanethidine and tyramine was considered probable $(22,29)$. Confirmation of this view is afforded by Matsumoto and Horita (30), who demonstrated that other indirect acting sympathomimetic amines (dexamphetamine and methamphetamine) of which tyramine is the prototype reduce the uptake of guanethidine by rabbit hearts and fulfill the conditions of competitive antagonism. Competitive antagonism between tyramine and guanethidine posits overlapping activities varying in strength. Thus, guanethidine has weak sympathomimetic actions and strong sympathetic nerve blocking activity, whereas the indirect acting sympathomimetic amines have strong sympathomimetic actions and weak sympathetic nerve blocking activity.

Additional confirmation of the close relationship between sympathetic nerve activity and angiotensin II is provided by observations on the augmentation by angiotensin II of the effects of sympathetic nerve stimulation and sympathomimetic agents. Thus, angiotensin II has been demonstrated by McCubbin and Page to augment the pressor effect produced by sympathomimetic agents (tyramine and ephedrine) and those procedures that release levarterenol from sympathetic nerve endings (6). Benelli and associates have shown potentiation by angiotensin II of the contractions of the vas deferens and spleen produced by sympathetic nerve stimulation (8).

Autonomic blocking agents have been considered to be ineffective in blocking the vasoconstrictor effect of angiotensin II $(4,31)$. The pressor response in normal human subjects to angiotensin II was shown by Laurence and Nagle to be unmodified by bretylium or guanethidine (32). An awareness that the pressor effect of angiotensin II may be related to several actions of angiotensin II, such as release of catecholamines from the adrenal medulla (7) and a positive inotropic effect (33), should invalidate any conclusions drawn from assuming a direct relationship between the pressor response and vasoconstrictor properties of angiotensin II. Guanethidine has been reported to be effective in treating the hypertension of occlusive renal arterial disease (34) in which angiotensin II probably initiates and may well sustain, in concert with other factors, the hypertension (31). The present investigation suggests that the efficacy of autonomic blocking agents in reducing the blood pressure of nephrogenic hypertension is predictable. Further exploration of the relationship between autonomic blocking agents and alterations of the release of the neurotransmitter is necessary before the present formulation of the relationship between autonomic blockade and angiotensin II may be considered more than tentative.

\section{Summary}

The effect of angiotensin II upon the renal vasculature is dependent upon two elements: 1) intactness of autonomic innervation of the kidney, and 2) a local effect that may have an autonomic nervous determinant either in terms of a critical store of sympathetic neurotransmitter or cholinergic involvement in the vascular effect of angiotensin II. Interruption of autonomic nervous activity by renal denervation and cervical cord section will reduce or abolish the renal vascular reactivity to angiotensin II. The effect of autonomic blocking agents on renal vascular reactivity to angiotensin II was predicted according to their activity at the neuroeffector site. Those agents, guanethidine, bretylium, and hydralazine, which influence sympathetic nervous activity by reducing the release of the neurotransmitter, block the renal vascular ac- 
tivity of angiotensin II, whereas those agents that primarily block receptor sites (phentolamine) or influence ganglionic transmission (hexamethonium) are without effect on the renal vascular response to angiotensin II. The restoration by tyramine of the renal vascular response to angiotensin II suggests the participation of a particular store of sympathetic neurotransmitter in the vascular activity of angiotensin II.

\section{Acknowledgments}

We acknowledge gratefully the assistance of Dr. Solomon D. Erulkar in performing the cervical cord sections. We are indebted to Dr. Calvin F. Kay for support, advice, and critical review of the work. Drs. George B. Koelle, Francis C. Wood, and Robert L. Volle gave helpful advice in the preparation of the manuscript. $\mathrm{Mr}$. Leon $\mathrm{H}$. King rendered excellent technical assistance. Dr. William E. Wagner of Ciba Pharmaceutical Co. generously supplied reserpine, phentolamine, guanethidine, and angiotensin II.

\section{References}

1. Yonkman, F. F., R. Jeremias, and D. Stilwell. Angiotonin myotropism. Proc. Soc. exp. Biol. (N. Y.) 1943, 54, 204.

2. Furchgott, R. F. The pharmacology of vascular smooth muscle. Pharmacol. Rev. 1955, 7, 183.

3. Laverty, R. A nervously-mediated action of angiotensin in anaesthetised rats. J. Pharm. Pharmacol. 1963, 15, 63.

4. Zimmerman, B. G. Effect of acute sympathectomy on responses to angiotensin and norepinephrine. Circulat. Res. 1962, 11, 780.

5. Bickerton, R. K., and J. P. Buckley. Evidence for a central mechanism in angiotensin induced hypertension. Proc. Soc. exp. Biol. (N. Y.) 1961, $106,834$.

6. McCubbin, J. W., and I. H. Page. Renal pressor system and neurogenic control of arterial pressure. Circulat. Res. 1963, 12, 553.

7. Feldberg, W., and G. P. Lewis. The action of peptides on the adrenal medulla. Release of adrenaline by bradykinin and angiotensin. J. Physiol. (Lond.) 1964, 171, 98.

8. Benelli, G., D. Della Bella, and A. Gandini. Angiotensin and peripheral sympathetic nerve activity. Brit. J. Pharmacol. 1964, 22, 211.

9. McGiff, J. C., and H. D. Itskovitz. Loss of the renal vasoconstrictor activity of angiotension II during renal ischemia. J. clin. Invest. 1964, 43, 2359.

10. Mandel, M. J., and L. A. Sapirstein. Effect of angiotensin infusion on regional blood flow and regional vascular resistance in the rat. Circulat. Res. 1962, $10,807$.
11. Zimmerman, B. G. Influence of several autonomic blocking agents on segmental vascular reactivity. J. Pharmacol. exp. Ther. 1964, 146, 200.

12. Snedecor, G. W. Statistical Methods Applied to Experiments in Agriculture and Biology. Ames, Iowa, Iowa State College Press, 1956.

13. McGiff, J. C. Regional flow response to cigarette smoking in the dog. Fed. Proc. 1963, 22, 509.

14. Green, A. F., and R. D. Robson. Comparison of the effects of bretylium, guanethidine and bethanidine on smooth muscle responses to different rates of sympathetic nerve stimulation. Brit. J. Pharmacol. 1964, 22, 349.

15. Tangri, K. K., and K. P. Bhargava. The central hypotensive action of 1-hydrazinophthalazine (C-5968). Arch. int. Pharmacodyn. 1960, 125, 331.

16. Hertting, G., L. T. Potter, and J. Axelrod. Effect of decentralization and ganglionic blocking agents on the spontaneous release of $\mathrm{H}^{3}$-norepinephrine. J. Pharmacol. exp. Ther. 1962, 136, 289.

17. McGiff, J. C. The renal vascular response to hemorrhage. J. Pharmacol. exp. Ther. 1964, 145, 181.

18. Robertson, P. A., and D. Rubin. Stimulation of intestinal nervous elements by angiotensin. Brit. J. Pharmacol. 1962, 19, 5.

19. Khairallah, P. A., and I. H. Page. Mechanism of action of angiotensin and bradykinin on smooth muscle in situ. Amer. J. Physiol. 1961, 200, 51.

20. Burn, J. H., and M. J. Rand. Sympathetic postganglionic mechanism. Nature (Lond.) 1959, 184, 163.

21. Jacobowitz, D., and G. B. Koelle. Histochemical correlations of acetylcholinesterase and catecholamines in postganglionic autonomic nerves of the cat, rabbit, and guinea pig. J. Pharmacol. exp. Ther. 1965, 148, 225.

22. Bhagat, B. Modification of the effects of guanethidine on cardiac catechol amines by various agents. Brit. J. Pharmacol. 1964, 22, 238.

23. Burn, J. H., and H. Froede. The action of substances which block sympathetic postganglionic nervous transmission. Brit. J. Pharmacol. 1963, 20, 378.

24. Roszkowski, A. P. An unusual type of sympathetic ganglionic stimulant. J. Pharmacol. exp. Ther. 1961, 132, 156.

25. Baum, T. Vascular reactivity of reserpine-pretreated dogs. J. Pharmacol. exp. Ther. 1963, 141, 30.

26. Kuntzman, R., and M. M. Jacobson. On the mechanism of heart norepinephrine depletion by tyramine, guanethidine and reserpine. J. Pharmacol. exp. Ther. 1964, 144, 399.

27. Crout, J. R., A. J. Muskus, and U. Trendelenburg. Effect of tyramine on isolated guinea-pig atria in relation to their noradrenaline stores. Brit. J. Pharmacol. 1962, 18, 600. 
28. Bhagat, B., and F. E. Shideman. Mechanism of the inhibitory action of guanethidine on cardiovascular responses to tyramine and amphetamine. J. Pharmacol. exp. Ther. 1963, 140, 317.

29. Day, M. D. Effect of sympathomimetic amines on the blocking action of guanethidine, bretylium and xylocholine. Brit. J. Pharmacol. 1962, 18, 421.

30. Matsumoto, C., and A. Horita. Studies of the antagonism of guanethidine by methamphetamine. Biochem. Pharmacol. 1963, 12, 295.

31. Page, I. H., and F. M. Bumpus. Angiotensin. Physiol. Rev. 1961, 41, 331.
32. Laurence, D. R., and R. E. Nagle. The effects of bretylium and guanethidine on the pressor responses to noradrenaline and angiotensin. Brit. J. Pharmacol. 1963, 21, 403.

33. Fowler, N. O., and J. C. Holmes. Coronary and myocardial actions of angiotensin. Circulat. Res. 1964, 14, 191.

34. Dustan, H. P., I. H. Page, E. F. Poutasse, and I. Wilson. An evaluation of treatment of hypertension associated with occlusive renal arterial disease. Circulation 1963, 27, 1018. 